\title{
Influence of Human Resource Management Practices on Organisational Performance at Atwima Mponua Rural Bank Limited
}

\author{
Moses Segbenya ${ }^{1}$ \& Joyce Ansah ${ }^{2}$ \\ ${ }^{1}$ College of Distance Education, University of Cape Coast, Ghana \\ E-mail:moses.segbenya@ucc.edu.gh \\ ${ }^{2}$ Atwima Mponua Rural Bank Limited, Kumasi \\ E-mail:joyceansah85@gmail.com
}

https://doi.org/10.47963/jobed.2020.08

\begin{abstract}
This study examined the effect of human management practices on organisational performance at Atwima Mponua Rural Bank Limited in Ghana. The study adopted a descriptive survey design from the quantitative approached. A census technique was deployed to sample all the 120 staf from all branches of the bank. Data were collected through a self-administered questionnaire and data were analysed with mean and standard deviation, Peason correlation matrix and multiple standard regression. The study found that the three most important variables/factors under human resource practices that strongly influenced the organisational performance of banks were recruitment and selection, performance appraisal and employee participation. Therefore, it is recommended that the management of Atwima Mponua Rural Bank Limited in Ghana should establish a dedicated human resource management department to formulate, implement and monitor a proper recruitment and selection methods, modern appraisal system and involve employees in decisions that affect workers to enhance organisational performance of the bank.
\end{abstract}

Keyword: Human resource practices, recruitment and selection, appraisal, employee participation, organisational performance. 


\section{Introduction}

Human resource practices relate to set of organisational activities that aim at managing a pool of human capital and ensuring that this capital is employed towards the achievement of its objectives (Bailey, Mankin, Kelliher, \& Garavan, 2018). Human resource management (HRM) is seen as a tool used to manage the human resources of every organisation. Studies have shown that organisations can create and sustain a competitive position through the management of non-substitutable, rare, valuable, and inimitable internal resources (Asumpta, 2019). In recent times, organisations have turned attention on achieving superior performance and competitive advantage through the best use of talented human resources as a strategic asset (Wagar \& Rondeau, 2006). Thus, human resource practices must now be aligned to business strategies for organisational success. No matter the amount of technology being adopted by companies to cut down cost, human resource still remains the most important resource of any success-oriented and profitable organisation.

The adoption of certain bundles of human resource management practices can positively influence organisational performance by creating powerful connections or detracting from performance when certain combinations of practices are inadvertently placed in the mix (Wagar \& Rondeau, 2006). Research has recorded a positive relationship between human resource management practices and corporate Performance (Asumpta, 2019; Bandari, 2020). Thus, to stimulate corporate performance, management is required to develop skilled and talented employees who are capable of successfully performing their jobs (Boohene, \& Asuinura, 2011).

HRM policies on selection, training and development, performance appraisal, compensation, promotion, incentives, work design, participation, involvement, communication, employment security, etc. must be formulated and implemented by HRM specialist with the help of line managers to achieve competence, cooperation with management, cooperation among employees, motivation, commitment, satisfaction, retention, presence, etc.

Over the last three decades, human resource management in Ghana can best be described as human resource administration or traditional human resource management, which focuses attention on administering benefits, policies, and operational functions (Ansah, 2018). Human resource administration delivers stand-alone activities, such as recruitment, training, career development, performance appraisal and compensation. These stand-alone activities are most at times not aligned with corporate vision and strategy (Ansah, 2018).

The banking sector has experienced growth over time with associated competition among both private and public banks (Segbenya, 2012). One of the growing banks competing with other commercial, savings, and development banks, among others, in Ghana in recent times is Atwima Mponua Rural Bank Limited (Ansah, 2018). Atwima Mponua Rural Bank Limited is a rural bank in the Ashanti Region located at Toase, off the Kumasi Bibiani Road in the Atwima Nwabiagya Municipal Assembly. The role of the bank as a rural bank serving clients in the rural and peri-urban areas in Ghana with products, such as savings and current accounts, fixed deposits, 'Susu' accounts, salary loans, overdraft, funeral loans, commercial loans, transport loans, agricultural loans and foreign remittances, cannot, therefore, be underestimated.

The bank currently contends with employee dissatisfaction with pay, which has slowed down productivity and could hinder organisational performance ((Ansah, 2018). Another challenge with the bank is low morale and motivation among staff (Atwima Mponua Rural Bank, 2015). Staffs are not motivated to work hard because when positions become vacant, external recruitment is done to fill these vacancies, which could influence commitment and organisational performance (Ansah, 2018).

There could be several human resource management related issues responsible for the low level of staff motivation of staff of the bank. Poor recruitment and selection process, unfair compensation system, discriminatory performance appraisal system, and the limited involvement of employees in decisions that affect them have the propensity of causing a low level of motivation among workers. The bank's ability to compete with other public and private banks will largely depend on the proper management of human resource-related issues herein termed as human resource practices (Asumpta, 2019). Thus, the need to examine how human resource practices (in terms of recruitment and selection, compensation, training and development, performance appraisal, employee involvement) affect organisational performance at the bank has become more urgent than before. In terms of gap in literature, earlier studies in Ghana on human resource practices by Asiedu-Appiah, Kontor and Asamoah (2013) were in the mining sector of Ghana; Bandari (2020) focused on Sustainability of Ghanaian Small and Medium Enterprises, Asumpta (2019) centred on private and public banks in the Tamale Metropolis of Ghana, and Segbenya, Aggrey and Peniana (2019) only looked at academic and non-academic staff with College of Distance Education. A similar study by Antwi, Opoku and Osei-Boateng (2016) also considered only selected Ghana Commercial Bank branches in Kumasi. Thus, these earlier studies have failed to consider the rural bank subsector, which also plays a key role in the financial landscape and the country's socio-economic development.

This gap, therefore, necessitated this study. Three research objectives, therefore, guided the study and these were to: Examine the perceptions of staff on human resource practices at Atwima Mponua Rural Bank Limited; Determine the relationship between human resource practices and organisational performance at Atwima Mponua Rural Bank Limited; and Assess how human resource management practices affect organisational performance. The study 
contributes to the literature on human resource management practices in the banking industry. Human resource management occupies a unique and sensitive position in the banking industry; therefore, a study of this nature helps Atwima Mponua Rural Bank Limited and the research society to appreciate the impact of human resource practices on organisational performance (Dwumah, 2014)

This study proposes appropriate human resource practices and the possible outcomes in rural bank settings. It also provides insights into the adoption of the "best fit" practices as a strategic response for Atwima Mponua Rural Bank in the near future. The larger community stands to benefit, since the improved performance of Atwima Mponua Rural Bank will enhance the living standard of most of the informal sector that deals with it and contributes significantly to the growth of the Ghanaian economy. The outcome of this study also prompts policymakers and implementers to pay due attention to HRM practices and the role it plays in achieving organisational performance. The findings and recommendations of this study provide a solid basis for rural banks to properly manage their human resources and serve as an opportunity for Atwima Mponua Rural Bank Limited to improve performance with the existing workforce. The rest of the paper focuses on the theoretical and conceptual perspective of human resource practices, methodology, results and discussion, and recommendations.

\section{Literature Review}

The strategic contingency theory, propounded by D.J. Hickson in 1971, guided this study. The strategic contingency theory, unlike other theories, does not seek to give a prescriptive, normative, nor descriptive view of what HRM practices ought to be. However, it argues that the HRM process does not take place in a vacuum, but rather within the context of the organisation's internal and external environment. As such, definitions of aims, strategies and policies activities, and the analyses of the role of the HR department are only valid in relation to organisational circumstances. This acknowledges the role of certain contextual factors, such as technology, competitive pressures, goals, culture, company size, and strategy employed, to create a distinctive management practice suitable for the organisation and serve as a source on distinction from others. Several studies have been conducted to identify the predictors of HRM practices in companies (Antwi, Opoku \& Osei-Boateng, 2016; Segbenya, Aggrey \& Peniana, 2019; Bandari, 2020).

\section{Conceptual Review on Human Resources Practices}

The resource-based view theory by Barney in 1961 on best practices suggests that universally, certain HRM practices either separately or in combination yield improved organisational performance (Saxena \& Tiwari, 2009). Several lists of "best practices" linked to the human resource functions include recruitment and selection, training and development, compensation, performance appraisal, and employee participation. Other best practices identified in the literature are also linked to total quality recruitment, zero defects recruitment team working and flexible job design selective hiring, employment security, self-managed teams, high compensation contingent on performance, extensive training, reduction in status differences and sharing information (Saxena \& Tiwari, 2009). Therefore, the next section explains the key elements or construct of human resource practices and how they influence organisational performance.

Recruitment and selection and organisational performance

Recruitment is the process of generating a pool of capable people to apply for employment. Selection is the process by which managers and others use specific instruments to choose from a pool of applicants who are more likely to succeed on the job(s) (Bratton \& Gold 2007). Recruitment and selection can play a pivotal role in shaping an organisation's effectiveness and performance. The process of recruiting and selecting may come in four stages: defining requirement, planning recruitment campaign, attracting candidates and selecting candidates (Armstrong, 2010).

Performance improvement is not only a result of a well-functioning system, but also depends on effective human resource strategies that succeed in recruiting and maintaining a committed and motivated workforce (Al-Ahmadi, 2009). Recruitment and selection have become ever more important as organisations increasingly regard their workforce as a source of competitive advantage. It is often claimed that the selection of workers occurs not just to replace departing employees or add to the number but rather to put in place workers who can perform at a higher level and demonstrate commitment (Armstrong, 2010). Recruitment and selection can be said to be grounded in organisation life cycle theory that suggests that the right calibre of human resource is needed at the formation, growth, maturity and decline stages of every organisation to remain competitive and to enhance performance.

Training and development and organisational performance

Training and development ( $\mathrm{T} \& \mathrm{D}$ ) are associated with an organisational attempt to improve workers' competency/skills and aptitude for their present or future work. Training and development are underpinned by the human capital theory that argues that training and development are "returnable investment" in workers. While 
training is seen to impart specific skills, development is said to be the learning opportunities designed to help employees grow. However, the two concepts are used in this study as one variable or meaning the same thing. For T \& D to have a better effect on performance, its design and delivery should be well executed. Segbenya and Titus (2020) indicate that adequate training improves employee communication and proficiency of performances as well as extending retention time. Poor performance due to inadequate job training can produce employee dissatisfaction and high labour turnover.

Compensation and organisational performance

Compensation relates to rewarding workers for the efforts and time used for the organisation's activities. Compensation management is not just about money, but with non-financial compensation (Segbenya, Aggrey \& Peniana, 2020). Compensation processes are based on compensation philosophies and strategies contained in the form of policies, guiding principles, structures, and procedures devised and managed to provide and maintain appropriate types and levels of pay, benefits and other forms of compensation. This constitutes measuring job values, designing and maintaining pay structure, paying for performance, competence and skill, and providing employee benefit.

However, compensation has a motivational effect and implies that having a compensation structure in which the employees who perform better are paid more than the average-performing employees is vital to enhancing organisational performance (Hewitt, 2009). The growing recognition and consensus that compensation promotes productivity is consistent with Drucker's early work that "happy workers are productive workers" (Hewitt, 2009). The importance of compensation for employee performance is supported by the equity theory that posits that every individual worker compares or evaluates the fairness of his compensation by comparing his/her input and output with that of others. Thus, perceived inequalities affect subsequent input and performance, affecting productivity and growth (Segbenya, Aggrey \& Peniana, 2020).

Appraisal/performance management and organisational performance

Performance appraisal of employees is the systematic evaluation of employees' performance and potential for development during a certain period of time by supervisors or others who are familiar with their performance (Pareek \& Rao, 2006). It is one of the oldest and widely used management practices and backed by the human capital theory suggesting that appraisal gives feedback for training and development considered an investment by the organisation for a return in the future in terms of increased performance. Performance appraisal is an indispensable tool for an organisation because its information is useful in decision making regarding promotion, merit increases, transfer, discharge, training and development. Not only is performance appraisal useful for the above issues, but it may also increase employee's commitment and satisfaction (Segbenya \& Bonsu, 2019). The increased competitive nature of the economy and rapid changes in the external environment have forced many organisations to shift from reactive performance appraisals to proactive performance management to boost productivity and improve organisational performance (Nayaab et al, 2011). Proactive performance management relates to the process of planning performance, appraising performance, giving its feedback, and counselling an employee or teams to improve performance (Armstrong, 2006).

Employee participation and organisational performance

The direct participation of staff to help an organisation fulfil its mission and meet its objectives by applying their own ideas, expertise and efforts towards solving problems and making decisions is termed as employee involvement. Research has shown that organisations that tap their people's strength are stronger and more aggressive than those that cannot (Segbenya \& Bonsu, 2019). Studies have shown that employee participation impacted on decision-making capability, reduced costs through the elimination of waste and reduced product cycle times and improved attitude regarding work (Jones, Kalmi, \& Kauhanen, 2010, Segbenya \& Bonsu, 2019). Other areas of importance in terms of the impact of employee involvement are empowerment, job satisfaction, creativity, commitment and motivation as well as intent to stay (Jones, Kalmi, \& Kauhanen, 2010). Thus, the organisational cycle theory's position, that workers' involvement at all stages of organisational growth (that is formation, growth, maturity, decline and death) is required for every organisation to remain competitive, is upheld.

Organisational performance

Researchers have different opinions on performance. Organisational performance continues to be a contentious issue in management research circles. Performance can be equated to the famous 3Es: economy, efficiency and effectiveness of a certain programme of activity. According to Richard, Devinney, Yip and Johnson (2009), organisational performance encompasses three specific areas of firm outcomes; financial performance (profits, return on assets, return on investment, etc), product market performance (sales, market share, etc), and shareholder return (total shareholder return, economic value-added among others). Organisational performance is the organisation's ability to attain its goals by using resources effectively and efficiently (Boohene, \& Asuinura, 2011). Boohene and Asuinura (2011) suggest that performance should not be confused with productivity. Productivity is a ratio depicting the volume 
of work completed in a given amount of time. Performance is a broader indicator that could include productivity as well as quality, consistency, effectiveness, efficiency and other factors. These later definition and indicators are, therefore, adopted as the definition for performance in this study.

The review on the various HRM practices variables shows how important they are in determining organisational performance. More so, their inclusion in this study has been entrenched by the position of Boohene and Asuinura (2011), who found a positive influence of human resource management practices (extensive training, selective hiring, compensation and incentives, employment security among others) on organisational performance (quality, cost reduction, flexibility, deliverability and commitment). In furtherance of this assertion, Delery and Gupta (2016) also found a positive influence of human resource management practices (namely human resource planning, staffing, incentives, appraisal, training, teamwork, employee participation, status difference, employment security) on organisation performance.

\section{Methodology}

The positivist epistemic approach from the quantitative perspective was adopted for this study. Specifically, the descriptive research design was adopted for this study. The descriptive design was adopted for this study because of its high degree of representativeness and the ease at which data can be gathered from a large population (Segbenya, Oduro, Peniana \& Ghansah, 2019). The design affords the researchers to collect a large pool of data from large respondents at a time through the cross-sectional design. The study population comprised the permanent staff population of Atwima Mponua Rural Bank Limited of one hundred and twenty (120) from eight Bank of the Bank in the Ashanti Region of Ghana. The census technique was adopted to sample all the population elements for the study, since the total population was on the lower side.

The study used a self-administered questionnaire as the data collection instrument. The questionnaire is comprised of 33 items for six variables of the study. The questionnaire was divided into two main parts. The first part focused on the demographic characteristics of respondents, such as age, sex, educational qualification, marital status and years of stay with organisation. Part two was divided into six sections according to the research objectives and the six variables guiding the study. These six variables were recruitment and selection, training and development, compensation, performance appraisal, employee participation and the organisational performance. All items forming each variable of the study were close-ended items due to the research design adopted for the study. All items of the questionnaire were measured on a four-point Likert scale with 1=Strongly Agree (SA), 2=Agree (A), $3=$ Disagree (D), and 4=Strongly Disagree (SD). The summary of the number of items for each variable and their corresponding reliability value can be seen in Table 1 . The overall Cronbach alpha of .874 confirms that the instrument was good for the data collection.

Table 1: Reliability Values for Variables of the Study

\begin{tabular}{lcc}
\hline Variable & No of items & Cronbach alpha \\
\hline Recruitment and selection & 06 & .810 \\
Compensation and rewards & 06 & .821 \\
Training and development & 06 & .729 \\
Performance Appriasal & 06 & .834 \\
Employee participation & 05 & .631 \\
Organisational performance & 04 & .821 \\
All variables & $\mathbf{3 3}$ & $\mathbf{. 8 7 4}$ \\
\end{tabular}

Source: Field data (2018)

The questionnaire was adopted as an instrument for data collection because it can secure relevant information effectively about phenomena that is not directly observable. It is also an efficient and effective method in reaching 
a larger group. Data was collected in 2018 adhering to all ethical requirements, such as confidentiality, anonymity, freedom to participate and withdraw, and no harm to research participants. Data were analysed with descriptive statistics, such as means and standard deviations, and inferential statistics, such as Pearson correlation and standard multiple regression.

Before data analysis was conducted, a test of normality of the data was done, and the results can be seen from Table 2. Normal distribution of the data requires the skewness values should range from -.5 to. 05 and the value of the skewness should not be more than twice the value of the standard error. Arithmetic Log 10 was used to ensure that both negative and positive skewed values were brought to normalcy and the results, as shown in Table 2, means that the data met the normality test. This is because all values for the skewness for all the variables were between the -.5 to. 05 thresholds.

Table 2: Test for normality of data

\begin{tabular}{lccccc}
\hline & $\mathrm{N}$ & \multicolumn{2}{c}{ Skewness } & \multicolumn{2}{c}{ Kurtosis } \\
& Statistic & Statistic & Std. Error & Statistic & Std. Error \\
\hline Recruitment and selection & 84 & .283 & .263 & -1.106 & .520 \\
Training and development & 84 & .381 & .263 & -1.511 & .520 \\
Organisational performance & 84 & -.328 & .263 & -1.121 & .520 \\
Compensation and reward & 84 & -.162 & .263 & 1.165 & .520 \\
Performance Appraisal & 84 & .209 & .263 & -1.052 & .520 \\
Employee Participation & 84 & .012 & .263 & -.962 & .520 \\
\hline
\end{tabular}

Source: Field data (2018)

\section{Results and Discussion}

The presentation for this section is based on the objectives guiding the study, and the presentation begins with the first objective, followed by the others.

\section{Perceptions of Staff on Human Resource Practices at Atwima Mponua Rural Bank Limited}

The results on perceptions of staff on human resource practices at the bank can be seen from Table 3. It is clear from Table 3 that respondents perceived only one factor-compensation or reward $(\mathrm{M}=3.1310, \mathrm{SD}=.50966)$ - to be very high. All the remaining five factors of the study were rated high with mean values ranging between $\mathrm{M}=2.5-2.9$ threshold. The least perceived factor, however, among all the six factors was organisational performance $(\mathrm{M}=2.6310, \mathrm{SD}=1.26852)$. (It must be noted that the significance of the mean values was based on the scale generated for the table).

Table 3: Perceptions of Staff on Human Resource Practices

\begin{tabular}{|c|c|c|c|c|c|}
\hline & $\mathrm{N}$ & Minimum & Maximum & Mean & Std. Deviation \\
\hline Compensation or reward & 84 & 1.00 & 4.00 & 3.1310 & .50966 \\
\hline Training and development & 84 & 2.20 & 3.80 & 2.9357 & .55810 \\
\hline recruiment and selection & 84 & 2.00 & 4.40 & 2.8500 & .71734 \\
\hline Performance Appraisal & 84 & 2.00 & 5.00 & 2.7310 & .68336 \\
\hline Employee Participation & 84 & 1.75 & 5.00 & 2.6786 & .83285 \\
\hline Organisational performance & 84 & 1.00 & 5.00 & 2.6310 & 1.26852 \\
\hline Valid N (listwise) & 84 & & & & \\
\hline
\end{tabular}

Source: Field survey (2018)

Scale: $2.0-2.4=$ low; $2.5-2.9=$ high and $3.0-3.5=$ very high.

Respondents rating of compensation very high ahead of the remaining factors of variables of the study suggest that compensation remains an important variable for workers in the banking industry. The results mean that both tangible and intangible components of total reward are essential for workers in the banking industry. The results, thus, agrees with the findings of Segbenya, Aggrey and Peniana (2019), that employee compensation is essential for workers. 
The Relationship between Human Resource Practices and Organisational Performance

The research question two was to determine the relationship between human resource practices and organisational performance at Atwima Mponua Rural Bank Limited. The relationship was determined, using five dependent variables/constructs of human resource practices (such as recruitment and selection, compensation and reward, training and development, performance appraisal and employee participation) and the dependent variableorganisational performance. The Pearson Correlation was used to determine the relationship. Table 4 presents the correlation results of the various constructs of human resource practice and the relationship with organisational performance.

The results show that out of the five contracts of human resource practices, only three had a statistical significance relation with employee performance. These constructs were variables Recruitment and Selection $\left(\mathrm{R}=.775^{* *} ; \mathrm{p}=.000\right)$; Employee Participation $\left(\mathrm{R}=.727^{* *} ; \mathrm{p}=.000\right)$; and Performance Appraisal $\left(\mathrm{R}=.690^{* *} ; \mathrm{p}=.000\right)$. The positive and significance of the correlation coefficients mean that any percentage increase in these constructs will result in the same percentage increase in organisational performance of the bank. Compensation $(R=0.66, p=.549)$, and training and development $(\mathrm{R}=.153, \mathrm{p}=.153)$, however, had a week relationship with organisational performance, respectively. They were all not significant despite recording positive correlation coefficient values.

The results that there was a statistically significant relationship exists between three independent variables, such as recruitment and selection, performance appraisal and employee participation, and the dependent variable, which was organisational performance, has several implications. The result suggests that rural banks' organisational performance is keenly linked to the calibre of employees and how these employees are employed. Thus, the wrong person for the wrong/right job termed as "square pegs in round holes" is very much linked to poor performance.

Table 4: Relationship between Human Resource Practice and Organisational Performance

\begin{tabular}{lcc}
\hline Human Resource Practices & \multicolumn{2}{c}{ Organisational Performance } \\
\cline { 2 - 3 } & $\begin{array}{c}\text { Correlation } \\
\text { Coefficient }\end{array}$ & Sig \\
\hline Recruitment and Selection & $.775^{* *}$ & .000 \\
Compensation and Reward & .066 & .549 \\
Training and Development & .153 & .164 \\
Performance Appraisal & $.690^{* *}$ & .000 \\
Employee Participation & $.727^{* *}$ & .000 \\
\hline **. Correlation is significant at the 0.01 level (2-tailed). & & \\
$*$ *. Correlation is significant at the 0.05 level (2-tailed). & & \\
\hline
\end{tabular}

Source: Field survey (2018), N=84

Additionally, the kind of target set for bank workers and how, and the regularity of appraisal (performance appraisal) is strongly linked to organisational performance. The results mean that when targets for workers are clear and are challenging to workers, it could spur high performance among rural bank workers in Ghana. Also, the involvement of workers in decisions that affect them as well as participation in the organisation's activities and its fortunes is directly linked to organisational performance in the banking industry. The results agree with that of Saxena and Tiwari (2009), that human resource practices, such as employee participation in decision making, recruitment and selection, and performance appraisal, are directly linked to organisational performance.

\section{Effects of Human Resource Management practices on organisational performance}

The third research question of the study was to assess how human resource practices affect the performance of the banks. Human resource practices were constituted with five constructs: recruitment and selection, compensation and reward, training and development, performance appraisal and employee participation. The dependent variable for the analysis of the third objective was organisational performance. The objective was analysed with standard multiple regression, and the results can be seen in Table 5.

Table 5: How Human Resource Practices affect Organisational Performance

\section{Coefficients $^{\text {a }}$}


Model
Unstandardised Coefficients
Standardised
Coefficients

Std. Error

Beta
Sig.

$\begin{array}{lccccc}\text { (Constant) } & 1.152 & .507 & & 2.272 & .026 \\ \text { Recruitment and Selection } & & .213 & .544 & 4.504 & .000 \\ \text { Compensation and Reward } & .097 & .125 & .039 & .778 & .439 \\ \text { Training and development } & 1.475 & .157 & .649 & 9.397 & .000 \\ \text { Performance Appraisal } & .013 & .277 & .007 & .046 & .964 \\ \text { Employee Participation } & 1.019 & .266 & .669 & 3.830 & .000 \\ \text { R } & & & .903 & & \\ \text { R square } & & & .816 & & \\ \text { a. Dependent Variable: organisational performance } & & & & \end{array}$

Source: Field survey (2018)

In terms of individual contribution of the independent variables (construct of human resource practices), it can be seen that the variable with the highest contribution in the explanation of the variance to organisational performance was the employee's participation with $(\beta=669, \mathrm{t}=3.830, \mathrm{p}<0.05)$; followed by training and development $(\beta=.649, \mathrm{t}=9.397, \mathrm{p}<=0.05)$; recruitment and selection with $(\beta=213, \mathrm{t}=4.504, \mathrm{p}<0.05)$; compensation and reward $(\beta 0.39, \mathrm{t}=.778, \mathrm{p}>0.05)$; and performance appraisal with $(\beta=007, \mathrm{t}=.046, \mathrm{p}>0.05)$. In terms of the overall contribution of all the independent variables to the explanation of the variance in organisational performance, all the variables explain about 81.6 percent of organisational performance, as can be seen with $\mathrm{R}$ square value of .816 . This means that there are other variables that this research did not consider to obtain $100 \%$ contribution of human resource practices and how it affects organisational performance.

The findings for objective three prove that good human resource practices, such as proper recruitment and selection, training and development, and employee engagement, directly affect organisational performance. Thus, if banks pay attention to these three significant variables, the possibility of increasing their performance is very high. This result is in tandem with what was found by Soomro et al. (2011), that HRM practices positively affect the performance of an organisation. Additionally, Nayaab et al. (2011) found that HRM practices, like recruitment and selection, training and development, and employee participation, significantly affect banks' performance is upheld in this study.

\section{Conclusion}

It can be concluded that human resource practices in the banking industry greatly influence organisational performance in the industry. The three most important variables/factors under the human resource practices that strongly influence banks' performance are recruitment and selection, performance appraisal, and employee participation. Thus, the proper management of human resource practices can significantly influence organisational performance in the banking industry. Therefore, incorporating human resource practices into business strategies and making the HR function "strategically proactive" is essential for the banks to be able to influence performance.

The proper management of human resource practices in the banking industry could create and sustain competitive advantage for the banks and improve organisational performance in the banking industry. Proper management of human resource practices is premised on dedicated human resource department and commitment from the management of the bank to ensure that it is strategically linked to the bank's overall goal. Unfortunately, Atwima Mponua Rural Bank Limited does not have a dedicated human resource management department for implementing and policing these human resource practices.

Based on the conclusion, it is, therefore, recommended that the management of Atwima Mponua Rural Bank (AMRB) should: establish a human resource department dedicated to human resource practices in the bank to deliver good human resources practices. This could start with Human Resource Practice Implementation Committee who will implement it and make sure that the activities are aligned to conform to national and international best practices, to ensure that irregularities and non-conformities are minimised, if not eliminated completely. Human resource experts should be employed to plan, implement and manage these HR functions. 
The bank should introduce proper recruitment and selection methods to ensure that the right skills and talents are brought on board to serve its stakeholders and enhance the organisational performance among its competitors. Input from exit interview could be valuable information in determining who to be hired as a worker for the bank. The bank should introduce the 360-degree modern performance appraisal method where all key stakeholders could get the opportunity to appraise staff. The feedback from the 360-degree could be very instrumental for improving employee and organisational performance of the bank.

This research also revealed that employee participation is a must for organisational performance. Thus, it is recommended that, in order to bring out the best in employees, employees' contributions should be regarded as important and taken in good faith. HR managers should understand team dynamics and find ways to bring disparate personalities together and make it a point to encourage teamwork and team spirit.

This research is limited to Atwima Mponua Rural Bank. Further research conducted into the HR practices of rural banks in Ghana will enable the better generalisation of the findings. Research into the other variables that could have a positive impact on organisational performance is also highly recommended. 


\section{References}

Al-Ahmadi. H, (2009). Factors affecting performance of hospital nurses in Riyadh Region, Saudi Arabia. International Journal of Health Care Quality Assurance, 22(1), 40 - 54.

Ansah, J. (2018). Human resource practices and organisational Performance: The case of Atwima Mponua Rural Bank Limited. (Master's dissertation, University of Cape Coast).

Antwi, J. O., Opoku, A.C. Ampadu S., \& Osei-Boateng M. (2016). Assessing the human resource management practices of public banks from employees' perspective: case study of selected branches of Ghana Commercial Bank, Kumasi. Global Journal of Human Resource Management, 4 (1), 13-30

Armstrong, M. (2006). Human resource management practice: A guide to people management. London: Kogan Page Publishers.

Armstrong, M. (2010) Essential human resource management practice: A guide to people management. London: Kogan Page Publishers.

Asiedu-Appiah, F., Kontor, E., \& Asamoah, D. (2013) Effect of human resource management practices on employee retention: perspectives from the mining industry in Ghana.

International Research Journal of Arts and Social Sciences, 2(2) 30-48.

Asumpta, A. M. (2019). Human resource management practices and employees' performance in private and public banks in the Tamale Metropolis, Ghana. (Masters dissertation, University for Development Studies, Tamale, Ghana).

Atwima Mponua Rural Bank Ltd (2015). Report on survey on staff agitations and problems at Atwima Mponua Rural Bank Limited. Kumasi: Atwima Mponua Rural Bank Ltd.

Bailey, C., Mankin, D., Kelliher, C., \& Garavan, T. (2018). Strategic human resource management (2nd ed). Oxford University Press.

Bandari, C (2020). Human resource management practices for sustainability of Ghanaian small l and medium enterprises. (Doctoral dissertation, Walden University).

Boohene, R., \& Asuinura, E. (2011). The effect of human resource management practices on corporate performance: A study of Graphic Communication Group Limited. International

Business Resource Journal, 4(1), 266-272. doi10.5539/ibr.v4n1p266.

Bratton, J. \& Gold. J. (2007). Human resource management: Theory and practice. London: (4th ed.) New York: Palgrave Macmillan.

Delery, J., \& Gupta, N. (2016). Human resource management practices and organisational effectiveness: "Internal fit matters" Journal of Organizational Effectiveness, People and Performance, 3, 139-163. doi.10.1108/JOEPP-03-2016-0028.

Dwumah, S. (2014). Human resource management practices in the Ghanaian rural-based banking sector. Evidence from the Ashanti Region (Doctoral dissertation).

Hewitt, A. (2009). Managing Performance with incentive pay. Journal of personnel Management, 7(1), 20-31.

Jones, D. C., Kalmi, P., \& Kauhanen, A. (2010). How does employee involvement stack up? The effects of human resource management policies on performance in a retail firm. Industrial Relations: A journal of economy and society, 49(1), 1-21.

Nayaab, H. H., Hamid M., Naseer F., \& Iqbal M. (2011). The impact of HRM practices on the organisational Performance: The study of banking sector in Okara, Punjab Pakistan. Interdisciplinary Journal of Contemporary Research in Business, 3(3), 661-672.

Pareek, U. \& Rao, T.V. (2006). Designing and managing human resource system. New Delhi: Oxford and IBH Publishing Private Company Limited.

Richard, P. J., Devinney, T. M., Yip, G. S., \& Johnson, G. (2009). Measuring organisational Performance: Towards methodological best practice. Journal of management, 35(3), 718-804.

Saxena Karunesh \& Tiwari Pankaj (2009). A study of HRM practices in selected IT companies of India. AIMS Journal of Management, 1(3), 29-44.

Segbenya, M. (2012). Importance of employee retention for attainment of organisational goals in Ghana Commercial Bank, Kumasi (Master's dissertation, University of Cape Coast).

Segbenya, M., Oduro, G.K.T., Peniana, F. and Ghansah, K. (2019). Proximity and choice of College of Distance Education (CoDE) of the University of Cape Coast for further studies. International Journal of Educational Management, 33(5), 1012-1034. https://doi.org/10.1108/IJEM-12-2017-0379.

Segbenya, M. \& Bonsu, O. (2019). Appraisal of managerial roles of study centre coordinators of College of Distance Education, University of Cape Coast. International Journal of Business and Management; 8 (5), 1-16.

Segbenya, M. \& Berisie, T. (2020). The effect of training and development on the performance of senior administrative staff at the University of Education, Winneba, Ghana. International Journal of Business and Management; 15 (2), 49-61. 
Soomro R. B., Gilal R. G., \& Jatoi M. M (2011). Examining the impact of human resources management (HRM) practices on employees' performance: a case study of Pakistani commercial banking sector. Interdisciplinary Journal of Contemporary Research in Business, 3(1), 865-878.

Wagar, T. \& Rondeau, K. (2006) Retaining employees in small and medium-sized firms: Examining the link with HRM. Journal of Applied Management and Entrepreneurship, 11(2), 3. 